\title{
On the Practice of College English Reading and Writing Course from the Perspective of POA Theory
}

\author{
Feipeng Li, Xuwei Li \\ College of Foreign Languages Education and International Business, Baoding University, Baoding, China \\ Email: lfp19801104@163.com
}

How to cite this paper: Li, F. P., \& Li, X. W. (2020). On the Practice of College English Reading and Writing Course from the Perspective of POA Theory. Open Journal of Modern Linguistics, 10, 560-568. https://doi.org/10.4236/ojml.2020.105032

Received: October 16, 2020

Accepted: October 23, 2020

Published: October 26, 2020

Copyright $\odot 2020$ by author(s) and Scientific Research Publishing Inc. This work is licensed under the Creative Commons Attribution International License (CC BY 4.0).

http://creativecommons.org/licenses/by/4.0/

\begin{abstract}
Established in the teaching status quo of college English in china, Production-oriented Approach (POA), proposed by Professor Wen Qiufang, advocates the teaching concept of "learning-using integrated", and constructs "motivating-enabling-assessing" classroom teaching process, thus providing new ideas for teachers to enhance teaching efficiency of college English classroom instruction. Through a comparative study of the control group which adopts traditional mode of classroom teaching and the experimental group that implements teaching methods based on POA Theory, the paper aims to explore the differences of teaching efficiency in college English reading and writing course under the two teaching ways mentioned above. By means of qualitative and quantitative studies, it is found that compared with traditional lecture-style classroom teaching, POA Theory applied in English reading and writing class under the framework of output-driven and input-enabled hypothesis can innovate the traditional approach of English teaching and promote students' ability to think and practice. In addition, the interaction between teachers and students and students' autonomous learning capacity are also effectively strengthened. With data collection and analysis, the author also digs up the reasons for the findings in this research from various perspectives. The reflections upon the research, its limitations and the conclusion are stated in the final part of this thesis.
\end{abstract}

\section{Keywords}

English Reading and Writing, Production-Oriented Approach, Teaching Model, Efficiency

\section{Introduction}

College English Curriculum Requirements points out that it is necessary to dig 
into rich humanistic connotation of college English courses in order to realize the organic unification of instrumentalism and humanism. College English teaching should be practical application-oriented and focuses on the cultivation of students' English application ability. Abiding by the concept of "learning-oriented", "combination of learning and utilizing", "cultural communication" and "key competence", the teaching procedures of production-oriented approach (POA) include the circulation of motivating, enabling and assessing (Wen, 2018). Taking the happening of effective classroom learning as a core, POA emphasizes language application and the cultivation of humanistic qualities, which accords with the overall objectives of current college English teaching. Reading and writing are two essential and important skills of English, which take up a comparatively large proportion of time in English learning and using. Reading and writing class has been playing a significant role in college English learning. However, there has been still no fundamental change in the English reading and writing of time-consuming and inefficient situation. It is highly required that close attention and related research on this field should be focused on. This study aims to examine the effect of the teaching design of college English reading and writing course based on POA theory and combines group cooperative learning, student-teaching and teacher-student collaborative assessment as the means of input-enabling to improve students' capacity of reading and writing

\section{Literature Review}

First put forward by Professor Wen Qiufang, "Output-driven Hypothesis" was developed into "Output-driven and Input-enabled Hypothesis" in 2013, and this theory was officially named as Production-oriented Approach (POA) in the $7^{\text {th }}$ International Conference on English Language Teaching in China, which provided compelling theoretical support and valid solutions for English teaching in China. With the perfection and development of the theoretical system of POA, scholars and teachers have explored the application and teaching efficiency of POA from different perspectives in recent years. Some teachers tried to apply POA to classroom teaching and conduct short-term empirical research. Zhang Wenjuan (2016) did a three-week classroom experiment on POA aiming to increase the efficiency of college English class. Feedbacks from students and coworkers indicated that classroom dynamics was effectively strengthened and the language output quality was greatly improved. Chen Xiaoqin and Tang Mingfeng (2019) applied POA theory to their teaching practice by conducting an 8-week teaching experiment and found that not only the students' English writing ability but also their self-teaching ability was largely improved.

Professor Wen Qiufang (2017) elaborated the theoretical framework of the using and assessment of POA teaching materials, including the using concept of teaching materials with teacher-led theory, output-determined theory and input material served theory, the using procedures of teaching materials and the validity evaluation criterion of teaching materials. Taking the textbook I English In- 
tegrated Course Book 1 Unit 4 as an example, Qiu Lin (2020) conducted a research on POA teaching materials from different angles, which provided guidance for teachers in the level of teaching practice including how to utilize teaching materials, design output objectives, evaluate output objectives and how to carry on POA teaching in large classes.

POA theory also aroused concern of foreign scholars like Ellis, Polio, Cumming and Matsuda. They expressed affirmation to theoretical base of POA, and offered proposals for the development, research method and research direction of POA. Ellis (2017) pointed that the opportunities for expressing their own ideas are rarely given to students in the process of enabling students to finish tasks based on POA, thus somewhat ignoring the social interaction in language learning.

\section{Methodology}

\subsection{Subjects}

One hundred seventy-eight non-English major undergraduates of Grade 2018 in four classes of four different departments in Baoding University with the ratio of male to female basically balanced were selected as the research subjects to participate in the pre-test, post-test and questionnaire survey. They were divided into two groups. One is the control group, and the other is the experimental group. The situation of students selected in the research is shown in Table 1. Totally, One hundred seventy-six students participated the pre-test and post-test. To ensure the scientificity of the experiment, students took a pre-test of writing. The results of $t$-test indicated that there was no significant difference in the scores between two groups (see Table 2).

\subsection{Instruments}

The research instruments employed in this study include reading and writing test papers, questionnaire, and statistical software SPSS 18.0.

Table 1. Basic situation of subjects.

\begin{tabular}{ccccc}
\hline & \multicolumn{2}{c}{ Control group } & \multicolumn{2}{c}{ Experimental group } \\
\cline { 2 - 5 } & Class 1 & Class 2 & Class 3 & Class 4 \\
\hline major & Math & History & physics & Chinese \\
number & 51 & 37 & 44 & 46 \\
\hline
\end{tabular}

Table 2. Result of wring test for the first time.

\begin{tabular}{ccccccc}
\hline & $\begin{array}{c}\text { Mean of } \\
\text { control } \\
\text { class }\end{array}$ & $\begin{array}{c}\text { SD of } \\
\text { control } \\
\text { class }\end{array}$ & $\begin{array}{c}\text { Mean of } \\
\text { experimental } \\
\text { class }\end{array}$ & $\begin{array}{c}\text { SD of } \\
\text { experimental } \\
\text { class }\end{array}$ & $t$-value & Significance \\
\hline $\begin{array}{c}\text { Writing for } \\
\text { the first time }\end{array}$ & 81.927 & 5.043 & 82.87 & 4.035 & -6.39 & 0.491 \\
\hline
\end{tabular}


The reading comprehension passages are chosen from CET 4 of December in 2016 and June in 2017. Two writing tasks refer to two general essays in no less than 150 words. The questionnaire is designed mainly to investigate students' attitude toward the efficiency of their English writing and reading practice under the POA teaching model.

\subsection{Procedures}

\subsubsection{Pre-Test and Post-Test}

Before the experiment, all the subjects in experimental class and control class were required to take a pre-test. The pre-test included reading comprehension and writing. The writing scores were made by two teachers and iWrite 2.0 system to guarantee the validity and reliability of the results. At the end of the experiment, all the subjects took a post-test with the same question types as pre-test paper. The part of writing was also scored in the same way. The data results of two tests were analyzed by SPSS 18.0.

\subsubsection{Teaching Practice}

The control class and the experimental class used the same textbooks. The POA-based teaching practice was conducted in experimental class for 16 weeks, totally 60 class hours, and the control class was taught in traditional teaching approach.

The POA-based teaching took speaking and writing as motivation. For example, in motivating period, teachers presented a challenging communication context to students who could realize their own shortcomings and develop learning desires in the process of communicative activities. The output could be realized in person or in groups, and the task of unit was introduced by output tasks. In the link of input enabling, teachers should instruct students to acquire knowledge and skills needed for the completion of output tasks. For instance, students learned articles in the form of group learning and found out the language forms and key information which were useful to deal with the output tasks. In the link of evaluation, teachers could adopt the combination of instant evaluation and delayed evaluation to give feedback to students' output results. What calls for special attention is that in the process of passage group learning, the difficult points students sum up should cover not only targeting items, contents and passage needed for output tasks, but also these of non-targeting in order to avoid the problem that understanding of the whole passage is neglected because of the ignorance of discourse and difficult sentences processing (Zhang, 2017).

\subsubsection{Questionnaire}

Besides pre-test and post test, a total of one hundred seventy-eight copies of questionnaires were distributed and one hundred seventy-six valid were collected. The questions mainly concentrated on students' attitude toward reading and their improvement of reading skills and ability. Meanwhile, students' autonomous reading ability and reading motivation were also investigated through the questionnaire survey. 


\section{Results and Discussion}

\subsection{Results and Discussion about Students' Reading Ability}

It can be seen from the result of Paired $\mathrm{T}$ test that there exist significant differences between pre-test and post-test ( $T$ reading in-depth $=-3.695, T$ gap filling $=-8.101, T$ fast reading $=-9.081, p<0.05)$ : the scores of each type of question in pre-test are significantly lower than that in post-test ( $M D$ reading-depth $=$ $-1.38, M D$ gap filling $=-1.61, M D$ fast reading $=-2.72$ ) (see Table 3 ).

Based on the result of questionnaire survey (see Table 4), POA teaching in reading effectively improved student's interest and confidence in reading as well as their reading ability. $90.6 \%$ students in experimental class expressed their deep interest in reading class. $70.6 \%$ students spent no less than one hour in reading after class. During motivating stage, the topic which was closely related to students' learning and life greatly aroused their interest in studies and desire to initiatively learn and pursue new knowledge. Meanwhile, teachers played an important role as "scaffold" when students encountered obstacles in learning particularly at the beginning of new lesson, thus greatly contributing to the building of their confidence and initiative. Students in experimental class were more likely to interact with teachers and classmates. $81 \%$ students had interaction with other classmates after class no less than five times a week. $77 \%$ students communicated with teachers no less than three times a week. $86 \%$ students were willing to complete learning tasks in and out of class. All these data were obviously higher than those in control class $(72 \%, 41 \%, 74 \%, 56 \%, 79 \%)$. Under the

Table 3. Difference of reading scores between pre-test and post-test.

\begin{tabular}{cccccccc}
\hline & \multicolumn{2}{c}{ Pre-test } & \multicolumn{2}{c}{ Post-test } & \multicolumn{2}{c}{ Comparison test } \\
\cline { 2 - 7 } & $M$ & $S D$ & $M$ & $S D$ & $M D$ & $t$ & Sig. \\
\hline Reading in-depth & 16.02 & 4.79 & 14.53 & 22.15 & -1.38 & -3.695 & 0.000 \\
Gap filling & 10.22 & 4.05 & 13.03 & 4.65 & -1.61 & -8.101 & 0.000 \\
Fast reading & 11.03 & 2.03 & 13.78 & 2.36 & -2.72 & -9.081 & 0.000 \\
\hline
\end{tabular}

Table 4. Students' feedback after POA-based reading class.

\begin{tabular}{lcc}
\hline & $\begin{array}{c}\text { Control } \\
\text { class }\end{array}$ & $\begin{array}{c}\text { Experimental } \\
\text { class }\end{array}$ \\
\hline Q1 increasing interest in reading & $72 \%$ & $90.6 \%$ \\
Q2 spending no less than one hour in reading after class & $41 \%$ & $70.6 \%$ \\
Q3 having interaction with classmates no less than five times a week & $74 \%$ & $81 \%$ \\
$\begin{array}{l}\text { Q4 having interaction with teachers after class no less than } \\
\text { three times a week }\end{array}$ & $56 \%$ & $77 \%$ \\
Q5 improving autonomous reading ability & $82 \%$ & $59 \%$ \\
Q6 having critical thinking after reading & $93 \%$ & $77 \%$ \\
Q7 having interest in completing tasks & $79 \%$ & $86 \%$ \\
\hline
\end{tabular}


concept of POA theory, the forms of tasks were designed according to different unit subjects and learning period in more various and flexible ways, attaching much more importance to practical application of language, practical needs of learning and lives for students, and the promotion of students' human diathesis and critical thinking skills as well. Students at different levels could acquire new knowledge and experiences in the whole course of assignment design, cooperative study and accomplishment. Therefore, students in experimental class had higher expectation for English class and could create more active classroom atmosphere.

\subsection{Results and Discussion about Students' Writing Abilities}

In order to ensure the validity and scientificity of the test, the scores of compositions in the pre-test and post-test were made by two English teachers and iWrite 2.0 system. The result of Paired $t$ test (see Table 5 ) indicates that there is significant difference in scores between two tests. $(t=-7.002, p<0.05)$ : students' writing grades of pre-test are significantly lower than those of post-test $(\mathrm{MD}=$ $-1.12)$.

Significant differences between pre-test and post-test $(t$ number of words $=$ $-4.101, t$ length of words $=-2.843, t$ length of sentence $=-3.517, t$ complex sentences $=-3.926, p<0.05)$ can be seen: the measured values of pre-test are significantly lower than those of post-test $(M D$ word number $=-6.28, M D$ word length $=-0.075, M D$ sentence length $=-1.12, M D$ complex sentences $=-1.33$ ) (see Table 6).

It can be seen from the result of questionnaire survey (see Table 7) that $87.8 \%$ students agreed that they made less mistakes in grammar than before, and 95.6\% students argued that English writing efficiency had been obviously enhanced. Besides, $85.6 \%$ students thought their writing motivation had been greatly promoted and their autonomous writing ability had been improved under the teaching model based on POA theory.

Table 5. Difference of writing scores between pre-test and post-test.

\begin{tabular}{ccccccc}
\hline \multicolumn{3}{c}{ Pre-test } & \multicolumn{3}{c}{ Post-test } & \multicolumn{3}{c}{ Comparison test } \\
\hline$M$ & $S D$ & $M$ & $S D$ & $M D$ & $t$ & Sig. \\
\hline 6.12 & 1.857 & 7.05 & 2.33 & -1.12 & -7.002 & 0.000 \\
\hline
\end{tabular}

Table 6. Difference of dimensions values between pre-test and post-test.

\begin{tabular}{cccccccc}
\hline & \multicolumn{2}{c}{ Pre-test } & \multicolumn{2}{c}{ Post-test } & \multicolumn{3}{c}{ Comparison test } \\
\cline { 2 - 8 } & $M$ & $S D$ & $M$ & $S D$ & $M D$ & $t$ & Sig. \\
\hline Number of words & 126.35 & 20.87 & 141.39 & 22.15 & -6.28 & -4.101 & 0.000 \\
Length of words & 4.36 & 0.29 & 4.42 & 0.29 & -0.075 & -2.843 & 0.010 \\
Length of sentences & 15.19 & 6.30 & 16.26 & 4.87 & -1.12 & -3.517 & 0.011 \\
Complex sentences & 8.42 & 3.32 & 9.58 & 3.83 & -1.33 & -3.926 & 0.000 \\
\hline
\end{tabular}


Table 7. Students' feedback to writing class in experimental class.

\begin{tabular}{lccc}
\hline \multirow{2}{*}{ Questions } & \multicolumn{3}{c}{ Total $(\mathrm{N}=90)$} \\
\cline { 2 - 4 } & Agree & Not sure & Disagree \\
\hline 1. Lowering grammatical errors & 79 & 6 & 5 \\
2. Promoting writing efficiency & 86 & 2 & 2 \\
3. Developing interest in writing & 72 & 15 & 3 \\
4. Arousing motivation in writing & 77 & 9 & 4 \\
5. Enhancing autonomous ability & 66 & 16 & 8 \\
\hline
\end{tabular}

Under the POA teaching mode, teachers adopted various methods and designed tasks like paragraph extension in order to help students to gradually compose longer articles. POA theory advocates that input should serve output and it emphasizes the teaching procedure of "input then output". In the classroom teaching, teachers, as the promoter for students' study, make timely and valid evaluation and feedback to students' output, which could better arouse students' attention to language errors. Writing is a headache for the vast majority of students because the promotion of writing ability depends on students' comprehensive proficiency in English. Under the guide of POA concept, students could acquire sufficient and targeted language information and expressions in the link of input-enabling, which could effectively strengthen their confidence and motivation in English writing.

\section{Conclusion}

POA theory creatively advocates the teaching concept of "learning-using integrated principle", and embeds "motivating, enabling and assessing" into English classroom teaching, which has been innovating college English teaching ideas and teaching model based on local. In this research, teachers and students gradually adapted themselves to the POA reading and writing class the main form which consists of cooperative learning, autonomous learning and teacher-students collaborative assessment. It is found that students' interest, motivation and autonomous learning ability in reading and writing have been significantly strengthened in experimental class based on POA teaching model. Meanwhile, students in experimental class made obvious progress in writing and reading abilities. There is significant difference in complexity and accuracy of writing compared with pre-test. Students' learning initiative and positivity both in reading and writing have been greatly improved under the POA teaching model.

Therefore, teachers are strongly advised to appropriately apply POA teaching concept and theory to their teaching of English reading and writing. Firstly, as a "scaffold" during teaching process, teachers need to make a scientific and highly-feasible teaching design. Secondly, the teaching idea of "learning-using integrated" is strongly required to be implemented in the whole process of teaching 
in order to better realize the objective of college English teaching. Thirdly, teaching assessment can't be neglected because it is an indispensable guarantee and important component of the reading and writing course. Meanwhile, both teaching ideas and the roles of teachers and students are required to be transformed.

There are still several problems that need continuous attention and reflection in the research. Firstly, teachers play an important role in the overall teaching process. The links of driving, enabling and evaluation have made new and higher demand for teachers. It is required that teachers should exert subjective initiative, adjust their teaching ideas and strategies and develop their own qualities so that they can fulfill their teaching tasks satisfactorily. Secondly, the difference in the initial level of students' foreign language has a big impact on POA teaching model. If there exists excessive gap among students, it will be hard for teachers to arrange output and input materials rationally, and identifying evaluation focus will also become difficult to realize. It seems that, therefore, POA teaching model is more suitable for college where layered teaching method is implemented. Besides, the link of evaluation needs teacher-student cooperation, and it demands students to actively participate in activities to express their ideas, so it is quite helpful to those who have strong motivations. However, it will be another challenge for teachers to mobilize the initiative of inactive students. In addition, it is essential that teachers should properly handle the relationship between students' autonomous learning and teachers' language skill instruction in the enabling link.

\section{Funding}

This research was supported by the Project of Hebei Applied Technology Universities Research Association: An Innovative Study on the Teaching Model of Foreign Language Reading and Writing Course Based on the Cultivation of Applied Talents from the Perspective of POA. Project number: JY 2019020.

\section{Conflicts of Interest}

The authors declare no conflicts of interest regarding the publication of this paper.

\section{References}

Chen, X. Q., \& Tang, M. F. (2019). Teaching Practice of College English Reading and Writing Course Based on Output-Oriented Approach. Journal of Wuzhou University, No. 4, 106-112.

Ellis, R. (2017). The Production-Oriented Approach: Moving Forward. Chinese Journal of Applied Linguistics, No. 4, 99-101. https://doi.org/10.1515/cjal-2017-0027

Qiu, L. (2020). Designing Enabling Activities in the POA: Criteria and Examples. Foreign Language Education in China, No. 5, 12-19.

Wen, Q. F. (2017). Using and Evaluation Theoretical Framework of POA Teaching Materials. Foreign Language Education in China, No. 2, 17-23, 95-96. 
Wen, Q. F. (2018). Cultivating Key Competencies through University Foreign Language Courses in the New Era: Reflections and Suggestions. Foreign Language Education in China, No. 8, 3-11.

Zhang, L. L. (2017). An Experimental Study on the Effectiveness of the Production-Oriented Approach. Modern Foreign Languages, No. 5, 369-376.

Zhang, W. J. (2016). College English Classroom Teaching Practice Based on POA. Foreign Languages and Their Teaching, No. 2, 106-114. 